\title{
Literafro - o portal da literatura afro-brasileira e sua re-configuração, entrevista com o idealizador do projeto, Prof. Dr. Eduardo de Assis Duarte
}

\begin{abstract}
Gustavo Tanus
Universidade Federal de Minas Gerais - UFMG - Minas Gerais - Brasil

Introdução

Surgido num momento em que as possibilidades de pesquisa oferecidas pela rede eram maiores do que aquilo que ela efetivamente ofertava, o portal literafro (disponível no endereço www.letras.ufmg.br/literafro) foi colocado já, naquele momento, como um espaço diferente, lugar de articulação de discursos sobre a produção literária de afro-brasileiros, havendo a divulgação de textos sobre os autores que compõem o universo estudado, suas obras e, também, textos da crítica. Como foi bem definido pelo entrevistado, o portal é um:

Espaço de divulgação, estímulo à pesquisa e à reflexão sobre a literatura dos afrodescendentes. Lugar rizomático, elo e ponto de encontro. Mas, também, ambiente lacunar, feito de presenças e ausências, que adquire sentido pelo que apresenta e pelo que ainda está por vir e apresentar. Espaço em construção, aberto sempre a visitas e intervenções. (literafro, s.d.).
\end{abstract}

Desde o começo, o objetivo não era o de se instituir apenas como um ponto de convergência de teorias e conceitos pré-existentes, mas como um espaço de/para articulação de pensamentos e perspectivas, de textos de escritoras negras e escritores negros e seus respectivos textos críticos de maneira rizomática, numa estruturação de discursos, cujo destino são os deslocamentos possíveis de serem realizados por pesquisadores dentro das academias e, pelos professores e alunos dentro das salas de aula.

Sendo um arquivo dinâmico de discursos são dispostas informações sobre o autor e, em alguns casos, sobre seu processo de escritura, sobre sua obra nas informações bibliográficas e apresentação de excertos e, também, de sua crítica, que é localizada, definida, reunida. Esses arquivos reconfiguram outras textualidades pelas possibilidades de leituras e por apontar para outros tantos arquivos. O portal recebe atualizações diárias, realizadas por bolsistas de iniciação científica como parte do processo de aprendizagem sobre a pesquisa e por que serão futuros professores sobre o ensino. Neste ano, o portal passa por uma atualização da sua linguagem, com o intuito de acompanhar as modificações tecnológicas destes novos tempos. 
O que motivou a criação do portal literafro?

Basicamente, a necessidade de ler os negros na universidade. De trazer a vertente afro-identificada, presente nas bordas da literatura brasileira canônica para nossas salas de aula. Logicamente, ler, para nós professores e estudantes, significa pesquisar, refletir e produzir conhecimento crítico sobre o material lido. Essa a razão primordial. O veio afro da literatura brasileira existe desde tempos imemoriais, mas não figura nos compêndios de nossa história literária. Essa ausência, que se repete no âmbito da produção literária feminina, sempre incomodou e sempre motivou iniciativas individuais de resgate de textos esquecidos. A partir de 2001, começamos a reunir pesquisadores de todas as regiões do Brasil, com vistas ao resgate de autoras e autores identificados com o projeto, hoje centenário, da literatura negra ocidental. Esse grupo reuniu 65 pesquisadores de 27 universidades brasileiras e do exterior. Como resultado desse trabalho surgiu, em fins de 2004, o Portal literafro - por uma decisão do grupo, grafado assim em negrito e com letra minúscula, como forma de destacar na grafia o lugar periférico ocupado por esses autores. E somente 10 anos depois, em 2011, conseguimos publicar, finalmente, a coleção Literatura e afrodescendência no Brasil em 4 volumes, com estudos detalhados de 100 autoras e autores negros brasileiros. Mas, a razão primordial foi - e continua sendo - esta: a de propiciar a estudantes, pesquisadores e demais interessados o acesso ao acervo literário afro-brasileiro como forma de resgatá-lo do esquecimento.

Há alguma diferença entre o projeto de quando ainda era uma ideia e no que se tornou hoje, passados 13 anos desde que entrou no ar? quais são as expectativas do novo portal?

De fato, em dezembro próximo estaremos completando 13 anos de atividades do literafro. Ao longo desse período, reunimos um conjunto considerável de dados e informações, mas também de material crítico que propicia a reflexão sobre 0 fenômeno. Além de textos sobre autoras e autores negros disponibilizados no portal ou linkados a outros sítios da web, oferecemos um seleto acervo com centenas de contos, poemas, crônicas e trechos de romances e peças teatrais, com textos escolhidos a dedo para leitura e deleite individual, como também para o trabalho em sala de aula. Somos educadores e um dos objetivos centrais do literafro é contribuir, disponibilizando materiais que propiciem a efetiva implantação da Lei 10.639 nas escolas de todo o país. Nesse sentido, acho que estamos cumprindo nosso propósito inicial. A internet veio para ficar e não pode ser ignorada jamais enquanto ferramenta pedagógica. A revolução digital a que estamos presenciando adquire uma velocidade impressionante a cada dia e nos obriga a lidar quase que cotidianamente com novas técnicas, tecnologias e formas de comunicação. Nesse contexto, surge a necessidade de aprimorarmos nossa plataforma, adequá-la a novas formas de circulação das informações, bem como ampliar o acervo em termos de conteúdo, como novos espaços para "Teatro Negro", "Ensaístas Negros", "Editoras Negras", por exemplo, além de abas para noticiário, envolvendo a cena negra na produção cultural como um todo. Vamos também dedicar um espaço especial à literatura infantil e infantojuvenil, além de termos uma presença mais efetiva em espaços como o Facebook e o Twitter. 
Em que você acredita que o portal desloca a noção mais tradicional de enciclopédia, aproximando-se de um local de entrelaçamentos de textualidades em rede?

Dado o caráter explícito de interação - recebemos contribuições de pesquisadores e estudantes de vários pontos do país, que nos mandam muitas indagações, mas também sugestões de nomes e obras, além de contribuições através de resenhas e artigos -, o portal cumpre o papel da enciclopédia viva, cheia de possibilidades novas, de algo que está se fazendo também em comunhão com quem o acessa. Com isto, tanto $\circ$ arquivo ganha em plasticidade e abertura, inclusive para reparar seus equívocos, quanto desaparece a figura passiva do mero espectador. Como Benjamin já havia alertado no século passado quanto à difusão dos meios de comunicação, o leitor passa também à condição de produtor. Quebra-se desta forma aquela velha via de mão única, em que a informação tinha uma origem e um destinatário definidos a priori e só funcionava no fluxo que se dirigia do professor aos alunos. $O$ portal não pode funcionar como um arquivo morto, simples depósito de dados e informações. Daí a importância dos voluntários que nos enviam contribuições para o resgate de novas autores, bem como notícias de suas pesquisas, descobertas e reflexões.

Você considera que a literatura brasileira contribuiu para a expressão da alteridade? em que medida?

De uma forma ou de outra, a literatura brasileira canônica sempre apontou para a diversidade cultural vigente no país. O problema é a forma como o fenômeno é representado, que sofre o impacto do contexto social de exclusão, vigente durante e depois do escravismo e, em especial, das teorias racistas vindas da Europa e adotadas por nossas elites. $O$ resultado é uma visão de cima para baixo que, via de regra, aprisiona a mulher e o homem negros nos estereótipos criados pelos brancos e largamente difundidos por nossa literatura. Um exemplo é o da "mulata assanhada", reduzida a animal erótico e figura noturna por excelência, desprovida de razão e de sentimentos, uma vez que dominada pelos instintos. E muitos textos de nossa tradição ainda completam o quadro, aleijando essa mulher no momento em que a fazem infértil, incapaz de gerar filhos sadios, repetindo a pior tradição do racialismo do século XIX. A esterilidade dessa personagem é fruto da fantasia masculina que consagra 0 sexo sem consequências ou compromissos, desumanizando a mulher e interditando a propagação da afrodescendência.

Como professor e pesquisador de literatura, diga-nos por que há uma distância entre a produção literária e a educação?

A instituição escolar enquanto propagadora do letramento literário, da formação do hábito de leitura e do ensino da Literatura Brasileira enquanto bem cultural da nacionalidade é, sem dúvida, um instrumento de canonização e de consagração pública de determinados textos e autores. E isso acaba criando uma camisa de força. Nos cursos de Letras, são formados os professores que irão levar seu conhecimento ou seja, seu repertório literário particular, somado ao que foi adquirido na faculdade para compartilhá-lo com seus alunos em forma de ensinamento. Roland Barthes afirmou, certa vez, que literatura é tudo aquilo que se ensina como tal... E é 
justamente nesse momento em que a camisa de força se manifesta de forma irredutível: devido à escassez de tempo, na graduação desse futuro professor são estudados, em grande medida apenas os autores considerados "grandes", responsáveis pela chamada "alta literatura". Praticamente não há espaço para quem foi relegado às margens do poder cultural, principalmente por esta alegada exiguidade de tempo, que leva os programas universitários a privilegiarem apenas os nomes consagrados pela tradição. E isto cria uma camisa de força que impede a renovação, o arejamento desse campo, com a presença de novos sujeitos e novas produções, sobretudo se localizadas nas "abas do Parnaso", como já dizia Luiz Gama, nosso primeiro poeta negro, em meados do século XIX. 